\title{
OPEN Author Correction: Characterisation of the Cyanate Inhibited State of Cytochrome c Oxidase
}

\section{Fabian Kruse, Anh Duc Nguyen, Jovan Dragelj, Ramona Schlesinger $\mathbb{B}$, Joachim Heberle, Maria Andrea Mroginski (i) \& Inez M. Weidinger (D)}

Correction to: Scientific Reports https://doi.org/10.1038/s41598-020-60801-0, published online 02 March 2020

The Acknowledgements section in this Article is incomplete.

"We thank Dorothea Heinrich, Jessica Stapel (FU Berlin) and Claudia Schulz (TU Berlin) for the preparation of CcO samples. We also would like to thank Ernst-Walter Knapp for his support in the calculations and Peter Hildebrandt for allowing us to measure in his lab. Financial support was provided by the German Research Foundation through the SFB 1078, projects A1, B4 and C2."

should read:

"We thank Dorothea Heinrich, Jessica Stapel (FU Berlin) and Claudia Schulz (TU Berlin) for the preparation of CcO samples. We also would like to thank Ernst-Walter Knapp for his support in the calculations and Peter Hildebrandt for allowing us to measure in his lab. Financial support was provided by the German Research Foundation through the SFB 1078, projects A1, B4 and C2. Open Access Funding by the Publication Fund of the TU Dresden.”

(c) Open Access This article is licensed under a Creative Commons Attribution 4.0 International License, which permits use, sharing, adaptation, distribution and reproduction in any medium or format, as long as you give appropriate credit to the original author(s) and the source, provide a link to the Creative Commons license, and indicate if changes were made. The images or other third party material in this article are included in the article's Creative Commons license, unless indicated otherwise in a credit line to the material. If material is not included in the article's Creative Commons license and your intended use is not permitted by statutory regulation or exceeds the permitted use, you will need to obtain permission directly from the copyright holder. To view a copy of this license, visit http://creativecommons.org/licenses/by/4.0/.

(C) The Author(s) 2020 